\title{
First report of black leaf mold by Cladosporium tenuissimum on Paulownia fortunei
}

\author{
Liu Yuelian $^{1}\left[\right.$ Chong Feiteng $^{1} \cdot$ Lu Shili $^{1} \cdot$ Chen Jie $^{1} \cdot$ Lin Pinling $^{1} \cdot$ Lin Xiao $^{1} \cdot$ Jiang Hongbin ${ }^{1} \cdot$ Zhang Xuhong $^{1}$
}

Received: 2 April 2021 / Accepted: 22 July 2021 / Published online: 23 August 2021

(c) Società Italiana di Patologia Vegetale (S.I.Pa.V.) 2021

Keywords Paulownia fortunei $\cdot$ Black leaf mold · Cladosporium tenuissimum

Paulownia trees [Paulownia fortunei (Seem.) Hemsl.] have good-quality wood and high economic value. In November 2020, black leaf mold was observed in about 1000 seedlings (disease incidence of about $80 \%$ ) in a 1.20 ha nursery in Zhanjiang $\left(21^{\circ} 17^{\prime} 51^{\prime \prime} \mathrm{N}, 110^{\circ} 18^{\prime} 16^{\prime \prime} \mathrm{E}\right)$, China. Early symptoms appeared on affected leaves as punctate black mold. The mildew stain gradually covered both sides of leaves. Three samples of symptomatic leaves were collected in the field. Margins of the diseased tissue were cut into $2 \mathrm{~mm} \times 2 \mathrm{~mm}$ pieces. The surfaces were disinfected with $75 \%$ ethanol for $30 \mathrm{~s}$ and $2 \%$ sodium hypochlorite for $60 \mathrm{~s}$. Single-spore isolates were obtained in vitro on potato dextrose agar (PDA) containing $0.2 \%$ chloramphenicol and incubated at $28{ }^{\circ} \mathrm{C}$. Olive-green velvety colonies appeared on the third day. Conidiophores with thick walls were septate and unbranched, and had a size of 70-140 $\mu \mathrm{m}$. Ramoconidia were cylindrical to clavate and had a size of 12.8-20.5 $\mu \mathrm{m} \times 4.5-5.8 \mu \mathrm{m}$. Conidia were single-celled, lemon-shaped, and smooth-walled, in chains, and had a diameter of 3-5.5 $\mu \mathrm{m}$. The morphological characteristics of isolates were consistent with those of Cladosporium tenuissimum Cooke (Bensch et al. 2012). The molecular identification of three representative isolates (CIP-1, ClP-2, and CIP-3) was performed through sequencing the nuclear ITS-rDNA region with ITS1 and ITS4 primers (White et al. 1990). The sequences of isolates were deposited in the GenBank (GenBank accession Nos. MW478318, MW478319, and MW478320). The BLASTn search of sequences (MF473305, MH383051, and MW646381) showed 100\% identity with $C$. tenuissimum. Meanwhile, the isolates (ClP1, CIP-2, and ClP-3) were preserved in glycerol (15\%) at $-80{ }^{\circ} \mathrm{C}$ in the China General Microbiological Culture Collection Center, Peking, China, CGMCC No: 2020CIP1, 2020ClP-2, and 2020ClP-3. The pathogenicity test was performed thrice. The inoculation and control groups $(n=5$ plants each) were sprayed with the spore suspension of isolates $\left(1 \times 10^{5}\right.$ per $\left.\mathrm{mL}\right)$ and sterile distilled water, respectively. Plants with three leaves were grown in pots in a greenhouse at $28{ }^{\circ} \mathrm{C}$. After seven days, the inoculation group had black mold, whereas the control group remained healthy. Reisolates from the inoculation group were identified as $C$. tenuissimum. C. tenuissimum was reported to cause leaf spot on castor in Zhanjiang, China (Liu et al. 2019). To our knowledge, this is the first report of $C$. tenuissimum as causal agent of black mold on P. fortunei in China and worldwide (Farr and Rossman 2021).

\section{References}

Bensch K, Braun U, Groenewald JZ, Crous PW (2012) The genus Cladosporium. Stud Mycol 72:(1):1-401

Farr DF, Rossman AY (2021) Fungal Databases, U.S. National Fungus Collections, ARS, USDA. Retrieved April 26, 2021

Liu YL, Yin XG, Lu JN, Li Y, Zhou YH (2019) First report of castor leaf spot caused by Cladosporium tenuissimum in Zhanjiang, China. Plant Dis 103(2):375

White TJ, Bruns T, Lee S, Taylor J (1990) In: PCR protocols: A guide to methods and applications. Academic Press, San Diego, CA, p 315

Publisher's Note Springer Nature remains neutral with regard to jurisdictional claims in published maps and institutional affiliations.
Liu Yuelian

mushwoman@126.com

1 Guangdong Ocean University, Zhanjiang 524088, China 